\title{
The Effect of Self-regulated Jigsaw IV on University Students'Academic Achievements and Attitudes towards English Course*
}

\author{
Esin Özdemir ${ }^{1}$, Ali Arslan ${ }^{2}$ \\ ${ }^{1}$ School of Foreign Language, Bulent Ecevit University, Zonguldak, Turkey \\ ${ }^{2}$ School of Eregli Education, Bulent Ecevit University, Zonguldak, Turkey \\ Correspondence: Ali Arslan, School of Eregli Education, Bulent Ecevit University, Zonguldak, Turkey
}

Received: March 14, 2016 Accepted: March 25, $2016 \quad$ Online Published: March 30, 2016

doi:10.11114/jets.v4i5.1453 URL: http://dx.doi.org/10.11114/jets.v4i5.1453

\begin{abstract}
This study aims to determine the effect of self-regulated jigsaw IV upon university students' learning a new grammar structure within EFL learning process and also their attitudes towards the English course. The research was carried out with 40 students studying in two different prep classes at Bulent Ecevit University Foreign Languages College in the spring term of 2011-2012 academic year. During the courses, while self-regulated jigsaw IV was carried out with the experimental group, a traditional method was performed in the control group. As quantitative data suggest; self-regulated jigsaw IV has significantly increased students' academic achievement compared to traditional method; however, it is slightly effective on their attitudes towards English. As qualitative data suggest; the students in the experimental group feel self-satisfied with their learning and they can use self-regulation skills in their autonomous studies.
\end{abstract}

Keywords: self-regulated learning, cooperative learning, jigsaw, academic achievement, attitude, English course.

\section{Introduction}

Today, technology and information systems are going through a process of change rapidly. These changes bring along the need for learning a common language, English, to keep up with these changes in the globalized world. Due to the countries producing technology use English or because it is the language of science. It is easier to build international communication, information exchange and economic relations with the help of a commonly spoken language. Learning a second language is also necessary for academic or professional life. Recognizing the importance of learning a second language for students, developed or developing societies include English language teaching (ELT) courses in their curriculum to meet this requirement. The new requirements such as technology in education lead to some changes in the curriculum. It turns from a subject-centered approach into a student-centered approach. In this respect, students learn not as passive participants but as participants actively involved in the learning process in which learning differs from person to person and also occurs individually. Therefore, the curriculum turns into a student-centered one where the students are not passive recipients but active constructors of knowledge. Students are strategic learners who are responsible for their own learning which is the basic characteristic of self-regulated learning. They set their own learning goals, try to regulate their own cognitions, motivations and behaviors, they are guided and limited by the contextual characteristics of their environments in an active and constructive process (Pintrich, 2000). They try to maximize the level of their own and the other students' learning while working in groups. When they work together in groups to achieve the learning goals in a social interaction, a cooperative learning occurs. Cooperative learning exists when students work together to accomplish shared learning goals (Johnson and Johnson, 1999). In foreign language learning, especially in the process of learning grammar rules, students should be able to work in cooperation with group interdependence, be aware of their needs or deficiencies and take necessary precautions. For an effective and efficient foreign language learning environment and academic achievement, they need to work collaboratively with self-regulated methods during the learning process. This study reveals the impact of combining self-regulated and

\footnotetext{
${ }^{*}$ This paper reproducted from master thesis written by first writer, and presented in $23^{\text {rd }}$ National Conference on Educational Science.
} 
cooperative learning techniques, when they are both used together, on students' academic achievements and attitudes towards the courses.

\subsection{The Need for Foreign Language Learning}

Each community, just like each individual, has its own language that expresses the ideas, values, and attitudes of its members (Amberg and Vause, 2009). By means of language, people can communicate with each other to maintain their lives, because language is a social communication tool for transferring thoughts and feelings. The rapid increase of communication channels in Turkey leads to the necessity of learning a foreign language, especially English, for working people such as businessmen, parliamentarians, administrators (Tok and Aribaş, 2008). In order to meet these demands, the need for foreign language learning and teaching arises. Foreign language is a language that surrounds a person as soon as he/she was born, it is not used as a means of communication or to carry out the formal relations unlike his/her native language, it is learned to communicate with native or native-like people after a conscious and planned teaching process (Karapirinler, 2006). Due to the globalized world, it has long been a necessity to learn a foreign language. It is widely acknowledged that globalization has made a considerable impact on multidimensional aspects of human life including the language policies of many countries (Kırkgöz, 2009). One of these countries is Turkey, where foreign language education is included in the curricula.

\subsection{Foreign Language Teaching in Compulsory Education}

Compulsory education in Turkey is 12 years divided into three as 4+4+4. English is included in curricula as a compulsory subject in Turkey. After the implementation of an 8 years primary law, starting from the 4th grade, English courses were made compulsory in the country. In 2006, Ministry of National Education made significant and radical changes in the implementation of foreign language courses in order to ensure compliance with to EU language policies. The Ministry of National Education has several projects in this regard, and it continues to make necessary efforts and innovations in accordance with the standards of the European Union. The Turkish Ministry of National Education has issued the new foreign language teaching policies in the official journal No. 26184, on 31 $1^{\text {st }}$ May, 2006 (MoNE, 2006). English course is compulsory in primary and secondary education. It starts in $2^{\text {nd }}$ grades and ends at the $12^{\text {th }}$ grade.

In Turkey, foreign language teaching is also an important process in higher education. In all of the universities, all the first-year students have to get a two-hour English class every week if they are not exempt from it by doing well in a proficiency examination. In many universities, some of the professional courses are partially taught in English and even in some of them, courses are entirely conducted in English. In higher education, the purposes of foreign language teaching are; to teach students the basic rules of that language, to improve their vocabulary, to make them understand and comprehend what they read or hear in a foreign language, to provide academic or professional communicative language skills which will be essential for them after their graduation.

\subsection{The Role of Grammar in Foreign Language Instruction}

Grammar is all the rules that explain the way the words of a language change themselves (morphology), the way they come together to form sentences of different types (syntax), and the way these sentences convey meaning and social function (semantics) (Akar, 2005). Not only does a language contain the set of symbols called words, but words are put together to make phrases and sentences (KuiperandAllan, 1996). Mastering a language is possible if somebody knows the rules and structures of that language system. Due to the fact that grammar is the most important element to form a language, it has an essential role in the process of learning a foreign language. In this process, it can be taught in many different ways and with different methods, one of which can be regarded as "cooperative learning".

\subsection{Cooperative Learning}

Cooperative learning is one of the most remarkable and fertile areas of theory, research and practice in education (Johnson et al., 2000). Being different from traditional learning methods, cooperative learning is a method in which students work collaboratively with a common goal in small and heterogeneous groups, helping each other's learning. Cooperative groups depend on the principles such as positive interdependence, individual accountability, promotive face-to-face interaction, interpersonal and small group skills and group processing. All students in groups have the equal opportunity to contribute to their teams. Cooperative learning is a useful education method to adapt the students to the learning environment and to the outer world. Cooperative learning is among the modern methods to be used in language classes effectively (Gömleksiz, 2007). In assessing the effectiveness of specific cooperative learning methods, however, there are a number of educators who have developed cooperative learning procedures, conducted programs of research and evaluation of their method, and then involved themselves in teacher-training programs that are commonly credited as the creators of modern-day cooperative learning (Johnson et al., 2000).

Johnson and Johnson (1999) assert that the aim of cooperative learning is to improve students' social and communicative skills, to increase their tolerance, and to raise their academic achievement. It can be used effectively for 
teaching foreign language due to its feasibility to all ages, levels and areas and it can create a student-centered communicative interaction in the classroom.

In the EFL classroom, jigsaw is a cooperative learning technique that requires everyone's cooperative effort to produce the final product. Just as in a jigsaw puzzle, each piece — each student's part—is essential for the production and full understanding of the final product. If each student's part is essential, then each student is essential (Mengduo and Xiaoling, 2010). One of the jigsaw techniques, Jigsaw IV was developed by Holliday in the late 1990s. It also has the same implementation phases as the other jigsaw techniques. However, there are also some differences that distinguish this technique from the others. The implementation of this technique consists of nine phases (Holliday, 2002);

In the first step, teacher introduces the material with summaries, video shows or activities and draws attention to the subject.

In the second step, teacher distributes tasks and subjects to students in their home groups.

In the third step, they form expert groups and work together collaboratively in their new groups.

In the fourth step, expert group quizzes are performed.

In the fifth step, they turn back to their home groups and work together collaboratively.

In the sixth step, home group quizzes are performed.

In the seventh step, review of the subject process is essential.

In the eighth step, individual assessment is performed.

In the ninth step, any of the materials that aren't adequately explored in the collaborative group work are retaught.

Although cooperative learning is a group learning process, students' individualities cannot be ignored (Arslan, 2011). In other words, in a cooperative learning process, each student is individually responsible for learning. In order to carry out these responsibilities, students also need to use self-regulated learning skills effectively, because during a self-regulated learning, the students become aware of their own learning process, organize them, use effective learning strategies, organize their environments suitable for their learning and evaluate themselves. In addition to being an important determinant of academic achievement, self-regulation skills are also crucial factors that contribute to individuals' life-long learning processes. Students' being active during cooperative learning, encouraging each other, the constant presence of promotive interaction among them are not only significant for them to get academic knowledge but also to get self-regulation skills (Arslan, 2011). Therefore, self-regulated learning needs to be viewed as a learning strategy.

\subsection{Self-regulated Learning}

Students' abilities to concentrate, to use the time efficiently, to believe in themselves, to correlate between information units, to formulate self-learning objectives and strategies, to reach self-learning objectives and organizational ability are closely related to self-regulation (Eker, 2014). "Self-regulated learning" which derived from the concept "self-regulation" is a process in which students are responsible for their own behaviours and learning. Self-regulation (or self-regulated learning) refers to self-generated thoughts, feelings, and actions that are planned and systematically adapted as needed to affect one's learning and motivation (Schunk and Ertmer, 2000). As one of the outstanding researchers of self-regulated learning (SRL), Zimmerman (1989) reorganized it on the basis of Bandura's (1986) social cognitive theory of triadic reciprocal causation. Self-regulated learning is a self-controlled process in which students transform their mental skills into task-oriented academic skills (Zimmerman, 2001). Self-regulated learning is described as an active participation of the learners to their own learning process metacognitively, motivationally and behaviourally (Zimmerman, 1986). It is a fusion of skill and will. The strategic learner is one who has learned to plan, control and evaluate his or her cognitive, motivational/affective, behavioural and contextual processes (Montalvo and Torres, 2004). They plan, conduct, control and evaluate their own behaviours and learning. At the end of the learning process, they are expected to be self-regulators. It is a complex process, containing cognitive, motivational and contextual elements (de Boer, et al.). As a learning strategy, self-regulated learning is described as a process whereby students activate and sustain cognitions, behaviours, and affects to their learning process (Çetin and Gelbal, 2008).

In the last fifteen years, numerous theories and models have tried to identify processes intervening in the self-regulation of learning, to establish relations and interactions between these and academic performance (Montalvo and Torres, 2004). One of them was proposed by Zimmerman (2008). It is a cyclical model which consists of the forethought, performance and self-reflection cyclical phases in the acquisition of self-regulated learning. For Zimmerman, these three phases represent a general sequence which the student steps through as they carry out the task. Self-regulated learning begins with the forethought phase where the processes such as goal setting, strategic planning, self-efficacy, outcome expectations, task interest/value, and goal orientation take place. In this phase, individuals intend to do the learning tasks 
and plan them (Alderman, 2004). It takes place before the actual performance and involves the processes of determining the phases which are essential for the action to be performed (Pintrich and Schunk, 2002). Goals are set and it helps the students to develop a positive mind set. The second phase, performance-control, consists of self-instruction, imagery, attention focusing, task strategies, metacognitive monitoring, self-recording processes. It is a phase in which students define the cases influencing their performances, take necessary precautions, develop appropriate learning strategies for themselves and monitor their progress while they are fulfilling their performances. Thus, they can increase the quality and efficiency of their performances. The third phase, self-reflection, which consists of self-evaluation, causal attribution, self-satisfaction/affect, adaptive/defensive involves reflection after the performance, and a self-evaluation of the learning process considering their own goals. Individuals react and respond to their self-regulated efforts in the learning process by evaluating the outcomes of their performance (Barnard-Brak et al., 2010) Clearly, students' use of high-quality SRL processes can enhance their motivation to continue additional cycles of learning (Zimmerman, 2008).

It is important that students are motivated to use the self-regulated strategies as well as cognitive and metacognitive strategies to achieve success (Üredi and Üredi, 2005). Students have to be motivated to adopt this intense form of learning, in which motivational and cognitive aspects are intertwined (Boekaerts, 1996). In a self-regulated learning process, one of the most important items that help students to be motivated is motivational beliefs (Üredi and Üredi, 2005). Self-efficacy is the most important source of student motivation. Chang (1997) and Moore (2005) have found that self-regulated learning activities have positive effects on self-efficacy. Pintrich and De Groot (1990) found out that none of the motivational variables was significant, but self-regulation was positively related to performance and cognitive strategy use in their study. According to the study of Zimmerman (2000), when studied as a mediating variable in training studies, self-efficacy has proven to be responsive to improvements in students' methods of learning (especially those involving greater self-regulation) and predictive of achievement outcomes. This empirical evidence of its role as a potent mediator of students' learning and motivation confirms the historic wisdom of educators that students' self-beliefs about academic capabilities do play an essential role in their motivation to achieve. Individuals who are self-regulated in their learning appear to achieve more positive academic outcomes than individuals who do not exhibit self-regulated learning behaviours (Barnard-Brak et al., 2010).

Arslan (2011) has asserted that the use of Jigsaw IV has increased the students' self-regulated score means due to the fact that they planned how to learn in groups and individually, used learning strategies, received feedback after the monitoring tests and gave peer feedback to each other. It has been found out that jigsaw IV technique has increased students' self-efficacy beliefs compared to traditional methods. Topsakal (2010) and Yapici et al. (2000) have found that cooperative learning has increased students' attitude towards course. It has been determined that in a teaching process with traditional methods only academic achievements of the participants have increased, but in a teaching process with Jigsaw IV technique it can be seen that their academic achievements have increased and their science anxiety has decreased (Doğru and Ünlü, 2012).

In this study, it was hypothesized that self-regulated learning would increase students' academic achievements and attitudes towards English course. So, the purpose of this study is to determine the effect of self-regulated jigsaw IV technique on the achievements and attitudes of university students in foreign language teaching.

\section{Method}

\subsection{Design}

In the research, experimental design was used. Non-equivalent control group pre-test and post-test design, which is one of the models of quasi-experimental design, was employed in the study. In this model, existing groups are studied and one of the groups is assigned as an experimental group and the other one as a control group. Tests are applied to both groups as a pre-test and post-test. The only difference between the two groups is the method or technique, the effect of which is being researched.

\subsection{Study Group}

This research was conducted on 40 EFL students attending two different prep classes of Bülent Ecevit University in Zonguldak province, in the 2011-2012 spring term. Considering their scores for proficiency exam, both participant classes were selected randomly from 160 students whose language levels are close to each other. One of the classes was defined as the control group $(\mathrm{n}=20)$ and taught with traditional teaching method while the other class, experimental group ( $n=20$ ), was taught with self-regulated jigsaw IV technique. At the beginning of the study, an achievement test and an attitude scale towards English Course were conducted to both groups as the pre-test. In the light of the data obtained from the scores, whether there were any significant differences among students were determined. At the end of the study, an interview form was used as a data collection instrument to determine the effects of self-regulated jigsaw IV on students in the experimental group. 


\subsection{Instruments}

\subsubsection{Academic Achievement Test}

Academic achievement test, which was examined by 4 English instructors and a doctor of curriculum and instruction, was developed by the first researcher. This test was developed for the purpose of measuring students' academic achievement on the subject "modals" in grammar courses. Multiple choice test which contained 65 items was applied to 160 students attending upper level classes as a pilot study in order to determine the difficulty and distinguishing indices of each item on the measurement draft, as well as wrong and incomplete questions. The items with low potential of distinguishing index were removed and the number of items was reduced to 35. In its final form, the Cronbach's Alpha coefficient was found as 0,85 . So, it can be inferred that this test measures modal auxiliaries of students reliably and validly.

\subsubsection{Scale of Attitude towards English Course}

A scale of attitude towards English course, which was developed by Aiken (1979) and adapted to the English courses after translating into Turkish by Tunç (2003), was applied to the students to measure their attitudes towards the English course. The scale, which was a 5 point likert type, consisted of 24 items, 19 being positive, and 5 negative items. The negative items were reversed in the course of analysis. The reliability coefficient of the scale was found as 0.85 for this study. It was applied as a pre-test and post-test for both groups.

\subsubsection{Interview}

To collect data related to the effects of self-regulated learning strategies on students, semi-structured interviews consisting of questions prepared by the first researcher were conducted. Questions on the form were examined by a curriculum and instruction expert and applied to 6 students selected randomly from the experimental group to get their opinions. The students' statements were quoted and transcribed identically. As a result of the interviews, the researchers coded statements and compared their codes in order to ensure the reliability of the data obtained.

\subsection{Process}

The achievement test and the attitude scale were applied to both groups as pre-test and post-test. Interviews with 6 students belonging to the experimental group were conducted. While a self-regulated jigsaw IV technique was performed in the experimental group, the researcher didn't intervene to control group. The researchers did not intervene to control group. In this group, lecturer taught lessons by traditional instructional methods such as lecture, dialog, discussion. At the beginning of the study, self-regulated learning strategies and jigsaw IV technique were explained to the students just after they were separated into home groups. In the experimental group, students in each home group made plans together setting common goals for themselves and they identified their learning strategies to reach these goals. During all stages of the study, they took a few tests and evaluation forms so that they could evaluate their own performance intermittently and compare them with their goals. They adjusted their strategies if necessary. At the end of the study, the group with the highest score was given an award and the missing or not comprehended parts of the unit were reviewed.

\subsection{Data Analysis}

SPSS (Statistical Package for Social Sciences) 16.0 was used for the analysis of the data collected. In quantitative analysis; in the first stage, Kolmogorov Smirnov test was applied in order to reveal if the data were normally distributed. When the results were analyzed, significance values (p) in all measurements were found to be greater than 0.05 . Therefore, it was clear that the data were normally distributed for all groups and so it was determined that parametric tests could be used. As a consequence of that, a paired samples t- test was used to determine the differences among pre-test and post-test and an independent samples t- test was used to determine the differences between the means of the experimental and control groups' academic achievement and attitude. In experimental designs, the fundamental aim is to test the cause and effect relationship between the variables (Büyüköztürk, et al., 2008). In analyzing qualitative data, the phases of self-regulated learning were used as a framework. For the data obtained from the interviews, descriptive analysis was used. In this kind of analysis the aim is to present the obtained findings in an organized and interpreted way. For this purpose, first of all, the obtained data is described in a systematic and clear way, then these descriptions are explained and interpreted, cause-effect relationships are analyzed and a conclusion is drawn (Yıldırım and Şimşek, 2008).

\section{Findings}

\subsection{Quantitative Findings}

At first step, pre-test and post-test means of the experimental and control groups were compared and then the gain score means of both groups were compared in order to determine if self-regulated jigsaw IV had any effect on students' achievements and attitudes. The means of achievement test $(\bar{X})$, standard deviation (sd), paired samples t test results are shown in table 1below: 
Table 1.The comparison of achievement and attitude pre-test and post-test means of the experimental and control groups.

\begin{tabular}{|c|c|c|c|c|c|c|c|c|c|c|c|}
\hline & & \multicolumn{4}{|c|}{ Experimental group } & \multicolumn{6}{|c|}{ Control Group } \\
\hline & & $\mathbf{N}$ & $X$ & SD & $\mathbf{t}$ & p & $\mathbf{N}$ & $\bar{x}$ & SD & $\mathbf{t}$ & $\mathbf{p}$ \\
\hline \multirow{2}{*}{$\begin{array}{l}\text { Achieveme } \\
\text { nt }\end{array}$} & $\begin{array}{l}\text { Pre-t } \\
\text { est }\end{array}$ & 20 & 4.85 & 2.49 & \multirow{2}{*}{-30.96} & \multirow{2}{*}{$0,000^{*}$} & 20 & 4.85 & 1.87 & \multirow{2}{*}{-8.994} & \multirow{2}{*}{$0,018^{*}$} \\
\hline & $\begin{array}{l}\text { Post-t } \\
\text { est }\end{array}$ & 20 & 30.85 & 2.56 & & & 20 & 19.00 & 6.44 & & \\
\hline \multirow{3}{*}{ Attitude } & & $\mathbf{N}$ & $X$ & SD & $\mathbf{t}$ & $\mathbf{p}$ & $\mathbf{N}$ & $X$ & SD & $\mathbf{t}$ & $\mathbf{p}$ \\
\hline & $\begin{array}{l}\text { Pre-t } \\
\text { est }\end{array}$ & 20 & 80.40 & 9.61 & \multirow{2}{*}{-1.879} & \multirow{2}{*}{0.076} & 20 & 78.94 & 8.72 & \multirow{2}{*}{2.030} & \multirow{2}{*}{0.057} \\
\hline & $\begin{array}{l}\text { Post-t } \\
\text { est }\end{array}$ & 20 & 85.40 & 6.02 & & & 20 & 72.10 & 8.29 & & \\
\hline
\end{tabular}

" $\mathrm{p}<0, \overline{05}$

Table 1 shows that the means of experimental group for achievement is 4.85 for pre-test, 30.85 for post-test and the control group's means are 4.85 for pre-test, 19.00 for post-test. According to the table, the achievement post-test of the experimental group is significantly higher than their pre-test. The increase in the attitude of the experimental group is slight and insignificant.

According to table 1, the achievement post-test of the control group is significantly higher than their pre-test. A decrease in the attitude of the control group can be seen, but this decrease is insignificant. It can be concluded that traditional method has increased students' achievements but not their attitudes.

In the study, the achievement and attitude gain scores of the experimental and control group students were analyzed and compared. The obtained data is presented in Table 2 below.

Table 2. The comparison of experimental and control group students' gain scores

\begin{tabular}{lllllll}
\hline \multirow{3}{*}{ Achievement } & & $\mathbf{N}$ & $\overline{\boldsymbol{X}}$ & $\mathbf{S D}$ & $\mathbf{T}$ & $\mathbf{p}$ \\
\cline { 2 - 6 } & Experimental & 20 & 26.00 & 3.75 & \multirow{2}{*}{6.64} & \multirow{2}{*}{0.019} \\
\cline { 2 - 6 } Attitude & Control & 20 & 14.15 & 7.03 & & \\
\cline { 2 - 6 } & Experimental & 20 & 5.00 & 10.45 & \multirow{2}{*}{-2.838} & \multirow{2}{*}{0.008} \\
\cline { 2 - 6 } & Control & 20 & -6.84 & 11.07 & & \\
\hline
\end{tabular}

According to Table 2, from the point of achievement gain scores; the experimental group students' achievement gain scores are significantly higher than those of control group students'. This means that the group which has performed self-regulated learning is more successful than the traditionally taught group. From the point of attitude gain scores; the significant difference between the means may seem as in favor of the experimental group, but the reason for this can be explained by the decrease in the control group students' attitude gain scores.

\subsection{Qualitative Findings}

At the end of the experimental process, six students, randomly selected from the experimental group, were interviewed in order to examine their views about using self-regulated learning in their independent studies and to find out whether they feel satisfied with their learning and evaluate their own learning. The interviews were recorded. After the interviews, the answers given by the students were analyzed in accordance with the self- regulated learning phases defined by Zimmerman (2005). The data obtained from the interviews are presented below as sub-categories.

\subsubsection{Forethought}

Forethought is a phase in which some activities needed for the study are applied before the experimental study. It is a phase consisting of goal setting and identifying strategies. Considering the answers given by the students, it can be seen that they use this phase in their studies. Some of their statements taken from the interviews are given below:

"... Errm..., I wanted to learn the subject very well, to get good grades for my group, to win the group award at the same time" (goal setting) (Student 2, boy).

"We wanted to get a higher grade, because this time we wanted to do better than the best, we tried hard, we had more effort. Previously we weren't setting goals. It was very effective in our study" (goal setting) (Student 2,boy).

"I set some goals for myself in terms of getting good grades for me and my group. I reached to my goal step by step. I liked studying in this way. I believe that I have learned better in the end"(goal setting)(Student 3, girl).

"I set some goals such as getting good grades, errm... awarding myself. I studied hard on my own. In my previous studies I wasn't setting goals"(goal setting) (Student 3, girl).

"We set some goals such as learning the subject, getting good grades to award ourselves. In order to reach our goals, we studied hard and determinedly"(goal setting)(Student 4, boy). 
"I set some goals such as getting good grades, awarding myself and winning the award for my group. I determined some strategies to reach the goal. I altered the things that I didn't like while studying. I made them suitable for me. I made studying more enjoyable. I did things like listening to music, etc. It was more efficient in my studies" (strategic planning/environmental structuring / arranging effort) (Student 6, boy).

"We revised. There was no memorization. So, we studied hard” (repetition and memorization)"(Student 3, girl).

"We recognised that this method increased our success. Errm... we took notes and underlined" (detailing) (Student 3, girl).

"That is to say, this method, we have noticed the difference in our success, because we had made a connection to our prior knowledge before we started the subject. We activated our prior knowledge"(Critical Thinking)" (Student 4, boy).

The statements of students show that at the beginning of the process they set their goals, plan how to study and identify their strategies to reach these goals before the performance.

\subsubsection{Performance Control}

This phase takes place during the learning process and the use of specific strategies helps students to become more successful. According to the interviews, it is seen that students mostly used metacognitive monitoring and help seeking strategy in this phase. The obtained data are presented below:

"I've realized that I observed myself. I observed myself better. I could understand my deficiencies better. I've found out how I can understand, in which environments Ican understand better. I've never done anything like this before (metacognition / monitoring / environmental structuring)” (Student 2, boy).

"I observed what I was doing, how I was studying with the help of my teacher. I thought that I would study in the same way in other courses. I've never done anything like this before (metacognition / monitoring / help seeking)" (Student 3, girl).

"Each member in the group began to control his/her friend through group work. I couldn't learn that much controlled in the past, because we didn't have such an environment (metacognition / monitoring)" (Student 5, girl).

The interviewed students have asserted that they used self-regulated learning strategies when it was difficult to learn a new grammar subject. During the learning process, they were aware of their deficiencies and monitored themselves most of the time.

\subsubsection{Self-reflection}

During the final self-reflection phase, the individual will self-evaluate based upon social comparisons and adjust the implementation of skills and strategies in the forethought and performance control phases for the next learning task. Self-regulated learning skills and strategies such as self-evaluation may be associated with the self-reflection phase (Barnard-Brak et al., 2010).

"It motivated me to the lesson. It made me enjoy the lesson and do something with my friends. I learned here how an appropriate study environment could be(self-satisfaction / environmental structuring)" (Student 1, boy).

"'Actually, it was very helpful. Most importantly it motivated me to the lesson. I began to enjoy the course more. My interest increased. I felt better... Of course, it had a positive effect. It made me feel more comfortable. Well, I felt more self-confident, I had more confidence. When we collaborated with our mutual friends, our interaction increased (self-satisfaction)"(Student 2, boy).

"During the time I was studying, this method helped me speak more comfortably in front of my group. It increased my self-confidence. It improved my interaction with my teacher and friends. It gave me more sense of self-confidence. This solidarity and togetherness made me enjoy the lessons more... My success rate increased (self-satisfaction / self-evaluation)” (Student 2, boy).

As it can be seen in the examples obtained from the interviews with the students in experimental group, after the use of these "forethought, performance and self-reflection" phases, it becomes clear that they can use self-regulated learning in their independent studies, evaluate their own learning and feel satisfied with their learning.

\section{Results and Discussion}

The purpose of this study was to investigate the effect of self-regulated jigsaw IV technique on students' achievements and attitudes towards the English course. At the same time, students' views on self-regulated learning use were analyzed. 
According to the findings of the study, the experimental group students who used the self-regulated learning strategies together with the jigsaw IV group process had a better performance than the control group students in the achievement test. Throughout the process of learning a new grammar subject based on self-regulated learning in jigsaw groups, the students defined effective learning strategies for themselves and then applied them. They checked if they could learn, and if not, they changed their strategies appropriately.

In this study, firstly it is clear that self-regulated jigsaw IV has a significant effect on grammar achievement when it is compared to traditional learning methods. Considering the gain scores of both experimental and control group, it can be concluded that the experimental group is more successful than the other one. Similar findings are supported by other studies that have used the jigsaw techniques (Doğru and Ünlü, 2012; Şimşek, 2007; Açıkgöz, 1993; Ghaith, 2003).The use of self-regulated jigsaw IV may also contribute to students' success in other courses, that's because it enhances and facilitates learning a new grammar subject which develops their language use better.

Secondly, self-regulated jigsaw IV learning has increased the experimental group students' attitudes towards English course, but this increase isn't significant. This can be explained by the decrease in the control group students' attitude scores. The reason of this insignificant increase may be the limitation of time for the unit. When the use of this technique lasts more, the increase in their attitudes may also be more significant. The reasons of this insignificant increase in the attitude rate can also be explained by the students' being accustomed to traditional teaching methods, not being ready for cooperation and being unaware of the method, the presence of students with undeveloped social skills within the groups, the increase of work load in cooperative learning processes, and the frequent use of quizzes and exams (Doğru and Ünlü, 2012). In the study of Mengduo and Xiaoling (2010), a conclusion was drawn that jigsaw technique is an effective way to promote student participation and enthusiasm as well as a useful technique for language learners to accomplish learning tasks in the EFL classroom. There are also similar studies with the same kinds of conclusions (Pintrich and De Groot, 1990; Israel, 2007).

Thirdly, after the use of self-regulated jigsaw IV during the experimental process, it has been concluded that the interviewed six students, randomly selected from the experimental group, can also use self-regulated learning not only in English course but also in their independent studies. It is also clear that before the performance they set goals and choose suitable strategies to reach these goals. During learning, they use help seeking, environmental structuring, arranging time and effort, detailing, self-recording and attention focusing strategies. After the performance, they can evaluate their own learnings, and they feel satisfied with their learning. Also, similar results have been found in the qualitative research of Sağırlı and Azapağası (2009), in which they analyze university students' self-regulated learning skills.

In the light of the findings obtained from the study, it has been concluded that self-regulated jigsaw IV technique is more effective than traditional teaching methods in foreign language teaching, specifically grammar.

It has been concluded that self-regulated jigsaw IV technique is useful and effective to increase the academic achievements of students. Therefore, some new proper studies adaptable to the higher education period are required for the acquisition of these skills. In this process, self-regulated and collaborative learning environments, which offer students the opportunity of making their own plans within the framework of their goals, working together with their peers, self-evaluating and correcting themselves at the end of the process, should be organized. The study is limited to only one grammar unit and to a specific sample. Therefore, it can't be generalized to all other units and students. In order to be able to get more valid results, various kinds of studies should be carried out with larger amounts of samples and greater number of units in different levels of classes. The role and motivation of the executive teacher performing the study is also important. Therefore, in order to increase the success rate of their classes, teachers can practice more. They can guide and assist the students to help them learn to use these skills in their whole life. To increase the teachers' motivations, it may be effective to allocate some time for activities such as seminars, courses, symposiums. The study is also limited to the grammar sub-learning area of an English course. It can be applied to other sub-learning areas of English courses. At the same time, it is possible to perform it also in other courses. For the future studies, it can also be conducted to investigate its effect on students' motivations and metacognitive skills.

\section{References}

Açıkgöz, K. (1993). İşbirliğine dayalı öğrenme ve geleneksel öğretimin üniversite öğrencilerinin akademik başarısı, hatırda tutma düzeyleri ve duyuşsal özellikleri üzerindeki etkileri. Paper presented in I. National Educational Sciences Congress in Ankara University, Ankara, Turkey, September 25 to 28,199.

Akar, N. (2005). Teaching grammar, bridging the gap between theory and practice. Ankara: Gündüz Education and Publishing.

Alderman, M. K. (2004). Motivation for achievement. ( $2^{\text {nd }}$ Ed.). NJ: Lawrence Erlbaum. 
Amberg, J. S., \& Vause, D. J. (2009). American English: History, structure, and usage. Cambridge: Cambridge University Press. http://dx.doi.org/10.1017/CBO9780511757792

Arslan, A. (2008) İşbirliğine dayalı öğrenmenin erişiye, kalıcılığa, özyeterlik inancına ve özdüzenleme becerisine etkisi. $\mathrm{Ph}$. D.Thesis, Unpublished. Ankara: Hacettepe University.

Arslan, A. (2011).The Effect of jigsaw iIV on gains, self efficacy belief and self regulation skill. ZKÜ Journal of Social Sciences, 7(13), 369-385.

Bandura, A. (1986). Social foundations of thought and action. New Jersey: Prentice-Hall, Inc. Englewood Cliffs.

Barnard-Brak, L., Paton, V., \& Yun, L. W. (2010). Profiles in self-regulated learning in the online learning environment. The International Review of Research in Open and Distance Learning, 11(1), 61-80.

Boekaerts, M. (1996). Self-regulated learning at the junction of cognition and motivation. European Psychologist, 1, 100-112. http://dx.doi.org/10.1027/1016-9040.1.2.100

Büyüköztürk, Ş., Kılıç Ç. E., Akgün, Ö. E., Karadeniz, Ş., \& Demirel, F. (2008). Bilimsel araştırma yöntemleri. Ankara: Pegem Akademi.

Çetin, S., \& Gelbal, S. (2008). Öz düzenlemeli öğrenme üzerine bir çalışma. Paper presented in $8^{\text {th }}$ International Educational Technology Conference in Anadolu University, Eskişehir, Turkey, May 6 to 8, 2008.

De Boer, H., Donker-Bergstra, A. S., Kostons, D. D. N. M., Korpershoek, H., \& van der Werf, M. P. (2013). Effective strategies for self-regulated learning: A meta-analysis. GION/RUG.

Doğru, M., \& Ünlü, S. (2012). The Effects of employing the Jigsaw IV technique in science and technology education upon students' motivation, science anxiety and their academic achievement. Mediterranean Journal of Humanities, 2(2), 57-66. http://dx.doi.org/10.13114/MJH/20122738

Eker, C. (2014). A comparative approach to self-regulation models. International Periodical for the Languages, Literature and History of Turkish or Turkic, 9(8), 417-433.

Ghaith, G. (2003). Effects of the learning together model of cooperative learning on English as a foreign language reading achievement, academic self-esteem, and feelings of school alienation. Bilingual Research Journal, 27(2), 451-474. http://dx.doi.org/10.1080/15235882.2003.10162603

Gömleksiz, M. N. (2007). Effectiveness of cooperative learning (jigsaw II) method in teaching English as a foreign language to engineering students (Case of Firat University, Turkey). European Journal of Engineering Education, 32(5), 613-625. http://dx.doi.org/10.1080/03043790701433343

Holliday, D. C. (2000). The development of jigsaw IV in a secondary social studies classroom, Eric Digest, Indiana US.

Holliday, D. C. (2002). Jigsaw IV: Using Student/Teacher Concerns to Improve Jigsaw III, Eric Digest, 465 687, SO 033888 , Indiana US.

Israel, E. (2007). Öz düzenleme eğitimi, fen başarlsı ve özyeterlik. Ph. D. Thesis, Unpublished. İzmir: Dokuz Eylül University.

Johnson, D. W., \& Johnson, R. T. (1999). Learning together and alone cooperative, competitive and individualistic learning. US: Pearson.

Johnson, D. W., Johnson, R. T., \& Stanne, M. B. (2000). Cooperative learning methods: a meta-analysis. $<$ http://tablelearning.com>(Retrieved on October 11, 2013).

Karapirinler, E. (2006). Özel İlköğretim okullarında ikinci yabancı dil öğretimi. Master Thesis, Unpublished. Ankara: Ankara University.

Kırkgöz, Y. (2009). Globalization and English language policy in Turkey. Educational Policy, 23(5), 663-684. <epx.sagepub.com> (Retrieved on September 29, 2013). http://dx.doi.org/10.1177/0895904808316319

Koenraad, K., \& Allan, W. S. (1996). An Introduction to English language: Sound, word and sentence .London: Macmillan Press.

Meng, D. Q., \& Xiao, L. J. (2010). Jigsaw strategy as a cooperative learning technique: Focusing on the language learners. Harbin Institute of Technology Chinese Journal of Applied Linguistics, 33(4), 113-125.

MoNE. (2006). Turkish ministry of national education English language curriculum. Tebliğler Dergisi, June, 2006/2585-Annex Official Journal: 31.05.2006/26184

Montalvo, F. T., \& Torres, M. C. G. (2004). Self-regulated learning: current and future directions. Electronic Journal of Research in Educational Psychology, 2(1), 1-34. 
Pintrich, P. R. (2000). The role of goal orientation in self-regulated learning. San Diego: California Academic Press. http://dx.doi.org/10.1016/b978-012109890-2/50043-3

Pintrich, P. R., \& De Groot, E. V. (1990). Motivational and self-regulated learning components of classroom academic performance. Journal of Educational Psychology, 82-1(2), 33-40. http://dx.doi.org/10.1037/0022-0663.82.1.33

Pintrich, P. R., \& Schunk, D. H. (2002). Motivation in education: theory, research and applications $\left(2^{\text {nd }}\right.$ Ed). New Jersey, Upper Saddle River: Pearson/Merrill Prentice Hall.

Sağırlı, M. Ö., \& Azapağası, E. (2009). Üniversite öğrencilerinin öğrenmede özdüzenlemeyi öğrenme becerilerinin incelenmesi. Ankara University Journal of Faculty of Educational Sciences, 42(2), 129-161.

Schunk, D. H., \& Peggy, A. E. (2000). Self-regulation and academic learning: Self-efficacy enhancing interventions. In M. Boekaerts, P. R. Pintrichand M. Zeidner (Eds.), Handbook of self-regulation. San Diego: Academic Press.

Shaaban, K., \& Ghaith, G. (2005).The Theoretical relevance and efficacy of using cooperative learning in the ESL/EFL Classroom.TESL Reporter, 38(2), 14-28.

Şimşek, Ü. (2007). Çözeltiler ve kimyasal denge konularında uygulanan jigsaw ve birlikte öğrenme tekniklerinin ögrencilerin maddenin tanecikli yapıda öğrenmeleri ve akademik başarlları üzerine etkisi. $\mathrm{Ph}$. D. Thesis, Unpublished. Erzurum: Atatürk University.

Tok, H., \& Arıbaş, S. (2008). Avrupa birliğine uyum sürecinde yabanc1 dil öğretimi. Inonu University Journal of Faculty of Education, 9(15), 205-227.

Topsakal, Ü. U. (2010).The Effectiveness of Cooperative Learning On Teaching 8th Class Unit 'Substance and Energy for Living Things. Journal of Ahi Evran University Journal of Faculty of Education, 11(1), 91-104.

Tunç, S. Ö. (2003). Use of language learning strategies in relation to student characteristics at Başkent University. Master Thesis, Unpublished. Ankara: Middle East Technical University.

Yapıcı, İ. Ü., Hevedanl1, M., \& Oral, B. (2009). The Effect of cooperative learning and traditional teaching methods on students' attitudes and achievement in systematic of seed plants laboratory course. Journal of Pamukkale University Journal of Faculty of Education, 26, 63-69.

Yıldırım, A., \& Şimşek, H. (2008). Sosyal bilimlerde nitel araştırma yöntemleri [Qualitative research methods in social sciences]. Ankara: Seçkin Yayınları.

Zimmerman, B. (2001).Theories of self regulated learning and academic achievement: an overview and analysis. Zimmerman B. and Schunk D. (Eds), Self regulated learning and achievement theorical perspectives. $2^{\text {nd }}$ Edition. London: Lawrence Erlbaum Associates.

Zimmerman, B. J. (1989). A social cognitive view of self-regulated academic learning. Journal of Educational Psychology, 81(3), 329-339. http://dx.doi.org/10.1037/0022-0663.81.3.329

Zimmerman, B. J. (2000).Self-efficacy: An essential motive to learn. Contemporary Educational Psychology, 25(1), 82-91. http://dx.doi.org/10.1006/ceps.1999.1016

Zimmerman, B. J. (2005). Attaining sef-regulation: A social cognitive perspective. In M. Boekaerts, P. R. Pintrichand M. Zeidner (Eds.), Handbook of self-regulation San Diego, CA: Academic Press.

Zimmerman, B. J. (2008). Investigating self-regulation and motivation: Historical background, methodological developments, and future prospects. American Educational Research Journal, 45(1), 166-183. http://dx.doi.org/10.3102/0002831207312909 